\title{
Changes in buoyancy and chemical composition during growth of a coastal marine diatom: ecological and biogeochemical consequences
}

\author{
Tammi L. Richardson ${ }^{1, *}$, John J. Cullen ${ }^{1,2}$ \\ ${ }^{1}$ Department of Oceanography, Dalhousie University, Halifax, Nova Scotia, Canada B3H 4J1 \\ ${ }^{2}$ Bigelow Laboratory for Ocean Sciences, McKown Point, West Boothbay Harbor, Maine 04575, USA
}

\begin{abstract}
Growth and sinking of the coastal marine diatom Thalassiosira weissflogii was studied during experiments in a $2.1 \mathrm{~m}$ tall water column. Under nutrient-replete conditions, $T$ weissflogii grew rapidly in the upper layer of the tank and cells exhibited nearly neutral buoyancy. Cells sank, however, after depletion of ambient nitrate. The growth and sinking of cells were well described by a simple model with nitrate-dependent growth and sinking terms. The best fit was obtained by describing the sinking response with a sigmoid function, where the time scale for increased sinking was $25 \mathrm{~h}$ after nitrate depletion. Smaller-scale batch culture experiments showed changes that were consistent with increased sinking upon depletion of nitrate: carbohydrate per $\mathrm{ml}$ of culture increased 2- to 5-fold over $3.5 \mathrm{~d}$, while protein per $\mathrm{ml}$ did not change significantly. After re-introduction of nitrate into the medium, carbohydrate:protein ratios reverted to their original values. Calculations show that intracellular density and cell sinking rate should change substantially due to fluctuations in carbohydrate and that increased ballast of carbohydrate was sufficient to cause the sinking observed in the tank. Changes in the buoyancy of small $(15 \mu \mathrm{m})$ diatoms such as $T$ weissflogii in response to changes in nutrient status have important ecological and biogeochemical implications. Nutrient-dependent changes in sinking rates can result in increased residence time of cells in the mixed layer of the ocean, and in enhanced transport of deep nutrients to the euphotic zone uncoupled from inputs of inorganic carbon.
\end{abstract}

KEY WORDS: Buoyancy $\cdot$ Chemical composition $\cdot$ Thalassiosira $\cdot$ Sinking $\cdot$ Carbohydrate $\cdot$ Protein

\section{INTRODUCTION}

Suspension and sinking of marine phytoplankton have received considerable attention in recent years due to increased interest in the flux of organic material to the deep sea (Michaels \& Silver 1988, Jahnke 1990). Since an organism's vertical position in the water column will ultimately determine its overall primary productivity and growth, an understanding of mechanisms of suspension and sinking is critical to accurate descriptions of marine ecosystems (Smayda 1970, Walsby \& Reynolds 1980).

Stokes' law is usually used to describe the sinking rate of phytoplankton cells (Smayda 1970, Vogel 1981, Oliver 1994)

·E-mail: tammi@ac.dal.ca

$$
V=\frac{2}{9} \frac{g r^{2}\left(\rho-\rho^{\prime}\right)}{\mu \phi_{r}}
$$

where $V$ is the sinking rate of the cell $\left(\mathrm{m} \mathrm{s}^{-1}\right)$ (positive in the downwards direction), $g$ is acceleration due to gravity $\left(\mathrm{m} \mathrm{s}^{-2}\right), r$ is cell radius $(\mathrm{m}), \rho$ is intracellular density $\left(\mathrm{kg} \mathrm{m}^{-3}\right), \rho^{\prime}$ is the density of sea water $\left(\mathrm{kg} \mathrm{m}^{-3}\right)$, $\mu$ is the dynamic viscosity of sea water $\left(\mathrm{kg} \mathrm{m}^{-1} \mathrm{~s}^{-1}\right)$ and $\phi_{r}$ is a dimensionless coefficient of form resistance, which is the ratio of the velocity of an equivalent sphere to that of cells of similar density and volume (Heaney \& Butterwick 1985). The $\left(\rho-\rho^{\prime}\right)$ term is known as excess density.

Motile phytoplankton are capable of directed swimming and can control their position in the water column (e.g. Cullen 1985), while the vertical position of non-motile phytoplankton is determined by interactions between the buoyancy of a cell and its physical 
environment (Smayda 1970). Cell buoyancy is affected by changes in excess density. Physiological changes in excess density may include changes in internal ion concentration (Gross \& Zeuthen 1948, Beklemishev et al. 1961, Anderson \& Sweeney 1977, 1978, Kahn \& Swift 1978), internal carbohydrate concentration (Villareal \& Carpenter 1990, Romans et al. 1994), or the production of gas vesicles, an adaptation found in many species of freshwater and marine blue-green algae (Walsby 1978, also reviewed by Oliver 1994). The most comprehensive studies of changes in excess density have concerned the buoyancy of blue-green algae, where overall buoyancy conferred by gas vesicles can be modified by changes in cellular carbohydrate (e.g. van Rijn \& Shilo 1985. Walsby et al. 1989, Ibelings et al. 1991, Romans et al. 1994).

Physiological changes in buoyancy may be independent of changes in density of surrounding sea water (Bienfang \& Szyper 1982) and of any morphological adaptations to suspension (Smayda \& Boleyn 1966a, b), though some morphological adaptations (like the production of chitin fibres by Thalassiosira weissflogij; see Walsby \& Xypolyta 1977) may contribute to an increase in the coefficient of form resistance which will slow the sinking speed of the cell. Cell buoyancy may depend on the light and nutrient status of the organism (Steele \& Yentsch 1960, Bienfang et al. 1982, 1983, Bienfang \& Harrison 1984, Granata 1987, Waite et al. $1992 a, b)$ and may require significant inputs of metabolic energy (Waite et al. 1992c).

Buoyancy changes give phytoplankton distinct ecological advantages. For example, it can be advantageous for cells to have low excess density so they will remain suspended in the illuminated waters of the euphotic zone. Often, however, nutrient levels in illuminated waters do not become significant until well below the euphotic zone (e.g. Hayward 1991). Thus, buoyancy changes that cause cells to sink to deeper layers to obtain nutrients are also of great benefit. Sinking of cells following diatom blooms is thought to be a survival strategy whereby cells become 'resting stages' in dark, cold water and are then ready to seed a new population when conditions are right (Smetacek 1985).

Changes in buoyancy may also cause cell sinking rates to slow and often result in accumulation of cells in subsurface maxima near nutrient gradients (Steele \& Yentsch 1960, Heaney et al. 1989). Lande \& Wood (1987) calculated residence times of cells in the surface mixed layer and nutricline of a 2-layer model of the upper ocean. Cells whose sinking rates slowed to $1 \mathrm{~m}$ $\mathrm{d}^{-1}$ at the top of the nutricline (from $4 \mathrm{~m} \mathrm{~d}^{-1}$ in the mixed layer) were shown to spend a substantially longer time in the mixed layer than cells with sinking rates that did not change, because the more slowly sinking cells had greater probability of being mixed back up to the surface. Prolonged cycles of sinking and resuspension meant that cells were 'shuttled' between nutrient-rich (deeper) waters and higher irradiance surface layers (Lande \& Wood 1987).

In this study, we focus on the buoyancy of a relatively small coastal marine diatom and on the connection between cell buoyancy, nutrient status, and cellular chemical composition. Experiments performed in a $2.1 \mathrm{~m}$ tall laboratory water column showed that a population of nutrient-replete Thalassiosira weissflogii was almost neutrally buoyant, but once nutrients ran out the nearly neutral buoyancy was lost. To determine the mechanism of sinking, we examined changes that occur in carbohydrate and protein during nutrient depletion and how changes in these constituents may affect cell sinking rates. Results are discussed in terms of the ecological advantages of buoyancy changes, both with respect to increased sinking rates upon nutrient depletion and decreased sinking rates when nutrient-replete. Finally, we discuss the potential biogeochemical consequences of buoyancy changes as a result of unbalanced growth.

\section{METHODS}

Tank experiments. Unialgal cultures of the marine diatom Thalassiosira weissflogii (Provasoli-Guillard Center for Culture of Marine Phytoplankton strain no. 1336) were grown in $10 \mathrm{l}$ polycarbonate carboys which contained 81 of sterile-filtered artificial sea water (ASW)-based f/2 medium (Guillard 1972) with nitrate concentration adjusted to $440 \mu \mathrm{M}$. Sterile filtration was done using a $0.2 \mu \mathrm{m}$ Culture Capsule filter (Gelman Sciences, Ann Arbor, MI, USA). Cells were grown at $20^{\circ} \mathrm{C}$, on a $16 \mathrm{~h}$ light: $8 \mathrm{~h}$ dark cycle. Illumination was from 7 Vita-Lite fluorescent lamps providing a quantum scalar irradiance of $150 \mu \mathrm{mol} \mathrm{m} \mathrm{m}^{-2} \mathrm{~s}^{-1}$ (photosynthetically active radiation, PAR) as measured by a Biospherical Instruments QSL-100 $4 \pi$ sensor placed just outside the culture containers.

Experiments were conducted in a $2.1 \mathrm{~m}$ tall, $0.29 \mathrm{~m}$ inner diameter (i.d.) opaque polyvinylchloride cylinder (Fig. 1; see Cullen \& Horrigan 1981, Heaney \& Eppley 1981). The bottom of the tank was surrounded by a barrel through which $9^{\circ} \mathrm{C}$ water was circulated to produce temperature stratification. The top portion of the tank was wrapped with an insulating blanket to conserve heat and to maintain a stable temperature gradient. Illumination was provided from above on a $12 \mathrm{~h}$ light: $12 \mathrm{~h}$ dark cycle (lights on from 08:00 to 20:00 h) using a $250 \mathrm{~W}$ metal halide Grow Lamp (Applied Hydroponics, Inc., San Rafael, CA, USA) shining through a running-water heat filter made of clear 


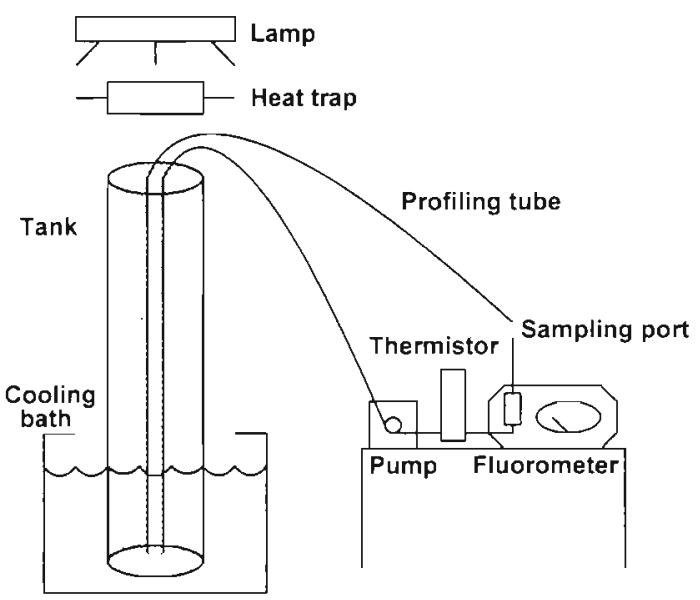

Fig. 1. Schematic of tank experiment apparatus. See 'Methods' for details

acrylic. Irradiance just below the surface water of the

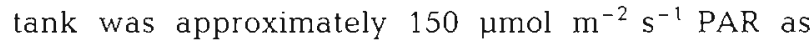
measured with a QSL-100 submersible sensor. Room temperature averaged $20^{\circ} \mathrm{C}$, though variations $\left( \pm 3^{\circ} \mathrm{C}\right)$ occurred due to heating by the lamp during the day and cooling of the ambient air at night; variations in water temperature were minimized by the insulating blanket.

The tank was filled with 100 l of sterile-filtered ASWbased $\mathrm{f} / 2$ medium without nitrate and was inoculated with the 81 culture of exponential phase Thalassiosira weissflogii described above. Nearly uniform vertical distribution of the culture was achieved by pumping the inoculum of $T$. weissflogii into the tank using a Masterflex peristaltic pump with $5 \mathrm{~mm}$ i.d. silicone tubing, while simultaneously mixing the tank by pulling the tube up and down. This resulted in an initial chlorophyll concentration of approximately $7 \mathrm{mg}$ $\mathrm{m}^{-3}$, an initial nitrate concentration of $30 \mu \mathrm{M}$, and an initial temperature of $20^{\circ} \mathrm{C}$. Once these conditions were established, the $9^{\circ} \mathrm{C}$ water was circulated through the barrel surrounding the bottom of the tank, and a sharp thermocline at about $150 \mathrm{~cm}$ depth was established within $12 \mathrm{~h}$ of inoculation. This thermocline remained nearly constant for the duration of the experiment (Fig. 2A). Cells were allowed to adjust to tank conditions for approximately $4 \mathrm{~d}$, after which routine sampling began.

Vertical profiles were conducted using a doubletube profiling system much like that described by Cullen \& Horrigan (1981) (refer to Fig. 1). Weighted silicone tubing (i.d. $1.6 \mathrm{~mm}$ ) was lowered into the tank. One end of the tube ran from the tank, through a Masterflex peristaltic pump (flow rate approx. $30 \mathrm{ml} \mathrm{min}^{-1}$ ) to the micro-flow-through cell of a Turner Designs Model 10-005R fluorometer. A return-flow tube carried this water to the depth from which it came, with little disruption of temperature stratification in the water column. Daily monitoring of 3(3,4-dichloropheny])-1, 1-dimethylurea (DCMU)-induced fluorescence ratios (Roy \& Legendre 1979, Vincent 1980) indicated no deleterious effects of pumping to photosynthetic capacity of cells. A thermistor was attached near the intake tube which gave vertical profiles of temperature. Using this double-tube system, profiles of fluorescence and temperature were performed at depth intervals of $20 \mathrm{~cm}$. Vertical profiles were done for $20 \mathrm{~d}, 6$ times daily (at 01:00, 07:30,11:00, 14:00, 17:00, and 20:00 h). Sampling times included one point at the end of the dark period (the $07: 30 \mathrm{~h}$ profile) and one point at the end of the light period (20:00 h).

Samples for cell counts, chlorophyll, and nitrate concentration were removed from a $\mathrm{T}$-connector in the return flow tube at 3 to 5 depths per profile. Depths chosen for sampling depended upon observed vertical distributions of fluorescence. Chlorophyll concentrations were determined by fluorescence after at least $24 \mathrm{~h}$ extraction in $90 \%$ acetone in the dark at $-10^{\circ} \mathrm{C}$ (Strickland \& Parsons 1972). Nitrate concentrations
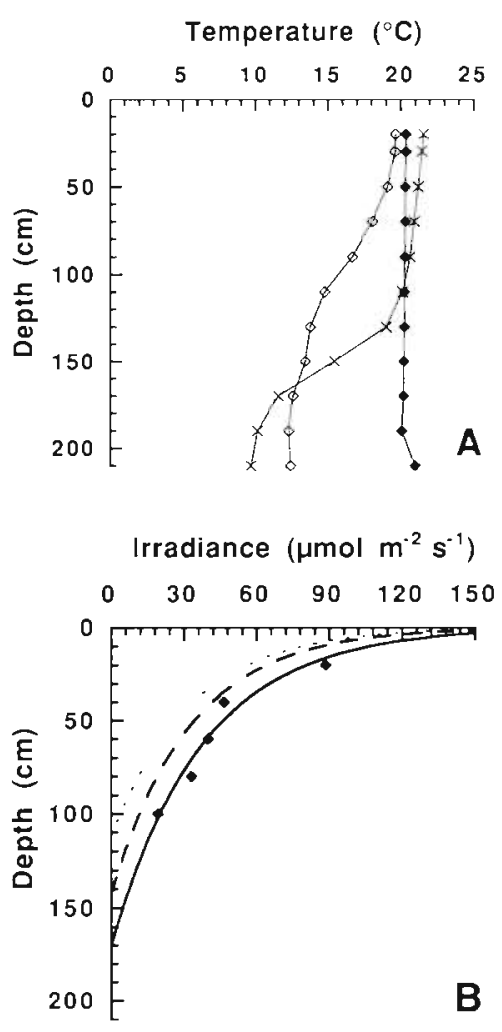

Fig. 2. (A) Temperature profiles at 3 time points during the tank experiment: Day $1(\bullet)$, Day $4(\diamond)$, and Day $10(x)$. (B) Irradiance profiles measured with distilled water in the tank (no cells) ( $\bullet$ with exponential curve fit as solid line) and modeled curves for Day $5(--)$ and Day $10(\ldots)$ of the experiment (see 'Methods' for details) 
were determined by a Technicon Auto-Analyzer II, and cell counts were done with an inverted microscope on cells preserved with a $1 \%$ solution of paraformaldehyde and glutaraldehyde (1:1 by volume) to a final concentration of $0.01 \%$. Fluorescence measurements were converted to chlorophyll concentration using a conversion factor calculated from determinations of chlorophyll at 3 to 5 depths in each profile, with intermediate values determined by linear interpolation of fluorescence:chlorophyll ratios. Specific rate of increase ( $k$ in $\left.\mathrm{d}^{-1}\right)$ of cells from the surface of the tank were determined by non-linear least squares regression analysis of an exponential growth curve, fit to the chlorophyll time series before depletion of ambient nitrate.

A profile of irradiance is shown in Fig. 2B. Due to the bulkiness of the light profiling apparatus, and its detrimental effects on thermal stratification in the tank, a light profile was determined only prior to the beginning of the experiment when the tank was filled with distilled water and there were no diatoms present. A rough approximation of the incremental attenuation of PAR due to increased chlorophyll throughout the experiment was modeled assuming a direct light path with attenuation due solely to absorption, with a specific absorption coefficient for phytoplankton of $0.015 \mathrm{~m}^{2}$ (mg chl) ${ }^{-1}$ (Kirk 1994) (Fig. 2B).

Batch culture experiments. For batch culture experiments, triplicate cultures of Thalassiosira weissflogii were grown in 101 polycarbonate carboys which contained $7 \mathrm{I}$ of ASW-based $\mathrm{f} / 2$ medium with nitrate concentration adjusted to near $30 \mu \mathrm{M}$. Cells were grown at $20^{\circ} \mathrm{C}$ on a $12 \mathrm{~h}$ light: $12 \mathrm{~h}$ dark cycle, and were illuminated with Vita-Lite fluorescent lamps providing an irradiance of $150 \mu \mathrm{mol} \mathrm{m} \mathrm{m}^{-2} \mathrm{~s}^{-1}$ measured just outside culture containers. A time-course experiment was conducted during which triplicate samples from each culture were taken morning and evening (just before lights-on and lights-off) for analysis of chlorophyll, nitrate, protein, and carbohydrate. Chlorophyll and nitrate were analyzed as described for tank experiments, protein was analyzed by the Biuret-Folin method of Dorsey et al. (1978) using bovine serum albumin (BSA) as standard, and carbohydrate was measured as glucose equivalents by the phenolsulphuric acid method of Dubois et al. (1956). Samples were taken before and after depletion of nitrate from the culture medium. Cells were allowed to go without nitrate for $3 \mathrm{~d}$, after which $100 \mu \mathrm{M}$ of $\mathrm{NaNO}_{3}$ was added to observe recovery of cells and accompanying changes in the accumulation of cellular constituents. Specific growth rates ( $k$ in $d^{-1}$ ) were determined by non-linear least-squares regression analysis of an exponential growth curve, fit to the chlorophyll time series obtained before depletion of ambient nitrate.

\section{RESULTS}

\section{Nearly neutral buoyancy in nitrate-replete Thalassiosira weissflogii grown in the experimental water column}

A total of 103 profiles were performed during the $20 \mathrm{~d}$ tank experiment. Under nitrate-replete conditions, Thalassiosira weissflogii had a specific rate of increase of $0.3 \mathrm{~d}^{-1}$ at the surface of the tank, reaching chlorophyll concentrations of $100 \mathrm{mg} \mathrm{m}^{-3}$ after $10 \mathrm{~d}$ (Fig. 3A). Cells exhibited nearly neutral buoyancy during this period. This assertion is based upon the follow-
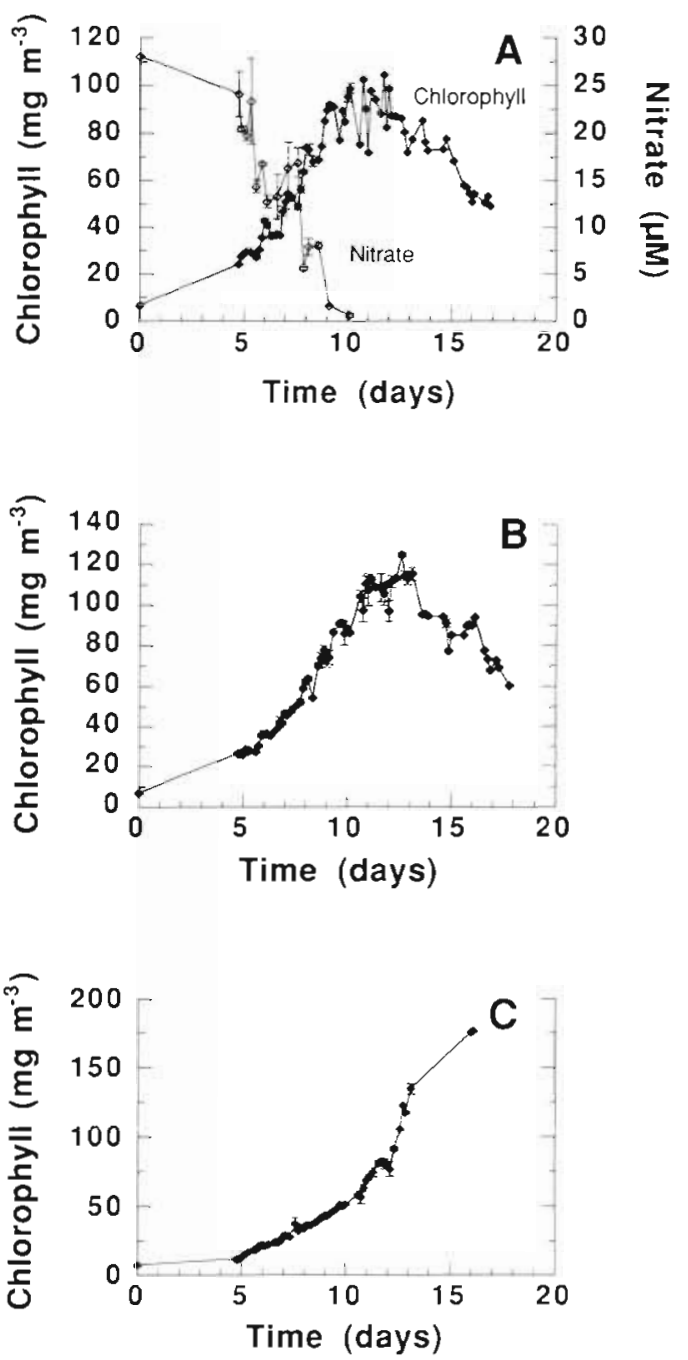

Fig. 3. Time-course of $(\mathrm{A})$ chlorophyll $(\bullet)$ and nitrate $(\diamond)$ in tank surtace waters, (B) chlorophyll at mid-depth $(110 \mathrm{~cm}$ ) and $(C)$ at the bottom $(210 \mathrm{~cm})$ during growth of Thalassiosira weisflogii in the tank. Error bars are $\pm \mathrm{SE}$ of triplicate measurements. Symbols with error bars are true chlorophyll determinations; those without error bars are chlorophyll values converted from fluorescence profiles 
Chlorophyll $\left(\mathrm{mg} \mathrm{m}^{-3}\right)$

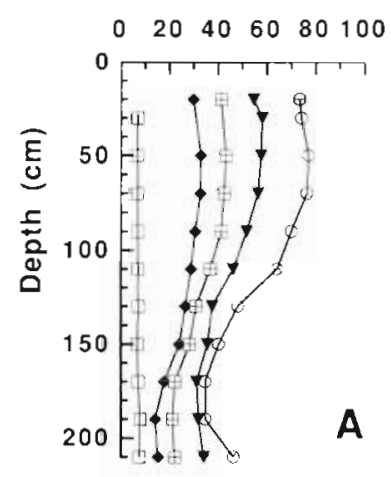

Chlorophyll $\left(\mathrm{mg} \mathrm{m}^{-3}\right)$

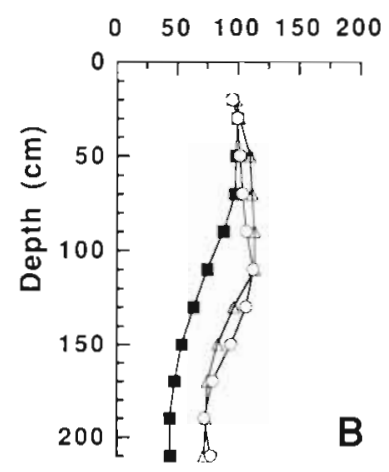

Chlorophyll $\left(\mathrm{mg} \mathrm{m}^{-3}\right)$

$0 \quad 50 \quad 100150200$

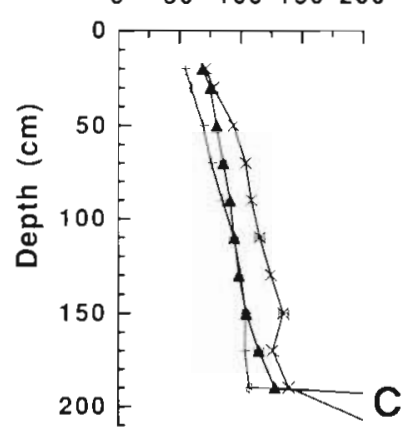

Fig. 4. Representative chlorophyll profiles done at 20:00 h daily during the tank experiment. (A) Profiles on Day 1 (initial), 6, 7, 8 , and 9 (in order, left to right). (B) Days $15(\mathbf{\square}), 17(\mathrm{O})$, and $18(\Delta)$. (C) Days $19(x), 21(\mathbf{4})$, and $22(+)$. Error bars are \pm SE of triplicate measurements. Symbols with error bars are true chlorophyll determinations; those without error bars are chlorophyll values converted from fluorescence profiles

ing observations: (1) growth rates of cells at the surface of the tank were the same as cells in batch cultures under similar conditions $\left(0.3 \mathrm{~d}^{-1}\right.$, discussed below), indicating that significant numbers of cells were not lost to sinking, (2) chlorophyll yield was as predicted for an initial nitrate concentration of $30 \mu \mathrm{M}$ (using a nitrate:chlorophyll relationship of $0.3 \mu \mathrm{mol} \mu \mathrm{g}^{-1}$ established during batch culture work), and (3) there was no noticeable accumulation of cells at the bottom of the tank $(210 \mathrm{~cm})$ until after nitrate was depleted from upper layers (see Figs. $3 \mathrm{~A}$ to $\mathrm{C} \& 4$ ).

Chlorophyll profiles done at 20:00 h each day (Fig. 4) show increases near the surface with minimal accumulation at depth until after Day 10, at which time the profile changed dramatically showing accumulation at mid-depth (Fig. 4B), then deep in the tank (Fig. 4C). Cell counts (Fig. 5) confirm that cells disappeared from

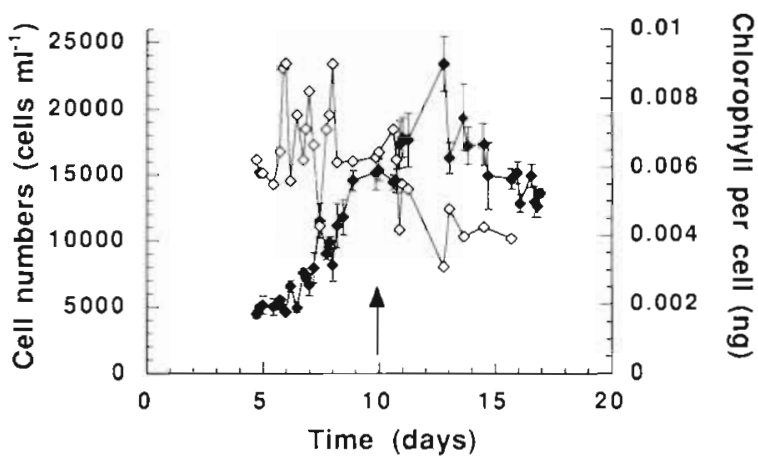

Fig. 5. time-course of cell counts $(\bullet)$ and chlorophyll per cell $(0)$ of Thalassiosira weissflogii taken from surface water of the experimental tank. Error bars are \pm SE of triplicate measurements. Arrow indicates time at which nitrate was depleted from surface waters surface waters. Cell count data and surface chlorophyll data (Fig. 3A) showed that cells did not sink immediately upon depletion of nitrate from the medium. Qualitative examination of chlorophyll data shows a time lag of approximately $48 \mathrm{~h}$; a slightly longer lag (60 h) is indicated by cell count data. The difference is consistent with a change in chlorophyll per cell after depletion of nitrate from culture medium (Fig. 5).

A diel series of profiles taken between 01:00 and 20:00 h on a typical day before nitrate depletion shows rapid accumulation of chlorophyll between 11:00 and 14:00 h with profiles keeping their characteristic shape throughout the day (Fig. 6).

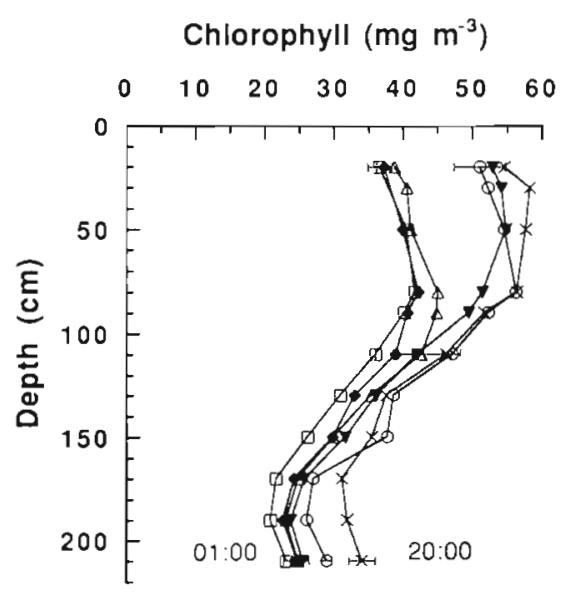

Fig. 6. Diel series of chlorophyll profiles done on a representative day (Day 8 ) before depletion of nitrate from surface waters of the tank. Profiles were done at 01:00 (ㅁ), 07:30(•), 11:00 ( $\Delta), 14: 00(\nabla), 17: 00(0)$, and $19: 30 \mathrm{~h}(x)$. The 07:30 profile is just before lights-on; 19:30 is just before lights-off. Error bars are \pm SE of triplicate measurements 

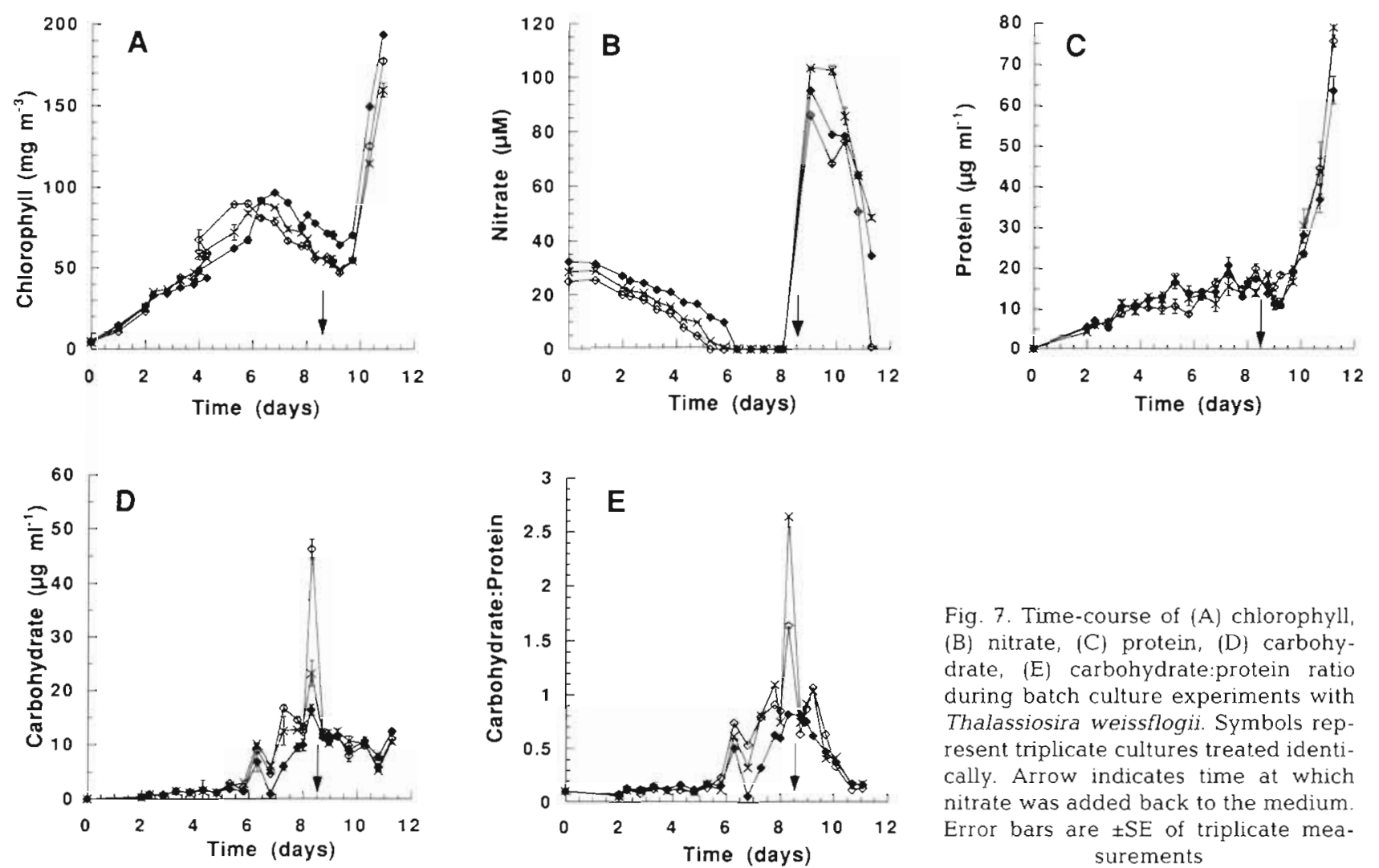

Fig. 7. Time-course of (A) chlorophyll, (B) nitrate, (C) protein, (D) carbohydrate, (E) carbohydrate:protein ratio during batch culture experiments with Thalassiosira weissflogii. Symbols represent triplicate cultures treated identically. Arrow indicates time at which nitrate was added back to the medium. Error bars are $\pm S E$ of triplicate measurements

\section{Growth of cells and changes in carbohydrate and protein during batch culture experiments}

Batch culture experiments examined changes in chlorophyll, protein, and carbohydrate during nitratereplete and nitrate-depleted growth of Thalassiosira weissflogii. Initially, cells grew exponentially at a rate of $0.3 \pm 0.01 \mathrm{~d}^{-1}$ (mean $\pm \mathrm{SE}$ of triplicate cultures) reaching chlorophyll levels of near $100 \mathrm{mg} \mathrm{m}^{-3}$ after $6.3 \mathrm{~d}$ (Fig. 7A). By that time, ambient nitrate had disappeared (Fig. 7B), protein synthesis had slowed (Fig. 7C), but cells continued to synthesize carbohydrate in a period of unbalanced growth (Fig. 7D). As in tank experiments, there was a noticeable decrease of chlorophyll after nitrate was depleted from culture medium (Fig. 7A). Overall, carbohydrate per ml of culture increased between 2.3 and 5.2 times during the nitrate-depleted phase of the experiment. Accordingly, time-course measurements of carbohydrate:protein ratios showed increases from pre-depletion values of 0.1 to values of over 2.5 . When nitrate was re-introduced after close to $3 \mathrm{~d}$ of nitrate depletion, however, cells recovered completely (Fig. 7C, D \& E). Protein synthesis increased, carbohydrate levels declined rapidly, and carbohydrate:protein ratios returned to their original values within $2 \mathrm{~d}$.

\section{DISCUSSION}

Daily profiles conducted during the growth of Thalassiosira weissflogii in the experimental water column showed that this diatom was almost neutrally buoyant under well-stratified conditions. Maintenance of buoyancy seemed closely tied to the nutrient status of the cells and changed after depletion of ambient nitrate. To quantify and examine this process, changes in chlorophyll and nitrate at the surface of the tank were described by an exponential growth equation modified by a Michaelis-Menten term for nitrate uptake and a loss term due to sinking:

$$
\mathrm{Chl}_{t}=\mathrm{Chl}_{t-\Delta t} e^{\left[\dot{\mu}_{\max }\left(\frac{N}{N+K_{\mathrm{s}}}\right)-W\right]_{3}}
$$

where $\mathrm{Chl}_{1}$ and $\mathrm{Chl}_{t-\Delta t}$ are chlorophyll concentrations ( $\mathrm{mg} \mathrm{m}^{-3}$ ) on Day $t$ and $t-\Delta t$ respectively, $\mu_{\max }$ is the maximum specific growth rate $\left(\mathrm{d}^{-1}\right), N$ is nitrate concentration $(\mu \mathrm{M})$ on Day $t, K_{\mathrm{s}}$ is the half saturation constant for nitrate $(\mu \mathrm{M}), \Delta t$ is the time since the last time step in days, and $W$ is a loss term $\left(\mathrm{d}^{-1}\right)$, due to sinking. Some component of this loss term is also due to chlorophyll degradation, as will be discussed later. Changes in surface water concentrations of chlorophyll and nitrate were modeled as discrete changes 
from an initial chlorophyll concentration of $7 \mathrm{mg} \mathrm{m}^{-3}$ an initial nitrate concentration of $30 \mu \mathrm{M}$ (initial values during the tank experiment), and a nitrate:chlorophyll ratio of $0.3 \mu \mathrm{mol} \mathrm{\mu g}^{-1}$. Generally, $W$ was modeled as:

$$
W=\frac{W_{s}}{1+100 \cdot e^{-\left(\frac{t-t_{d}}{T_{s}}\right)}}
$$

where $w_{\mathrm{s}}$ is the maximum specific loss rate $\left(\mathrm{d}^{-1}\right), t$ is time in days, $t_{\mathrm{d}}$ is the time of nitrate depletion (d), and $T_{\mathrm{s}}$ is a time scale for increased sinking (d). This formulation varies $W 100$-fold, from 1 to $100 \%$ of the maximum specific loss rate, $w_{5}$, with a sigmoid function consistent with changes in chemical composition during unbalanced growth (Cullen \& Lewis 1988); cells reach $10 \%$ of $w_{\mathrm{s}}$ at approximately $2.5 T_{\mathrm{s}}$.

Parameters for Eqs. (2) \& (3) were estimated by a least-squares non-linear curve fitting routine in Systat, version 5.2. The optimal combination of parameters was determined using a grid search method on a spreadsheet, where the aim was to minimize the sum of the squared deviations of the modeled vs measured chlorophyll.
Four possible time-courses were modeled by varying the form of $W$, the loss term. Chlorophyll and nitrate distributions were modeled for the case where there was no sinking of cells upon nitrate depletion, that is, if $W$ was set to zero through the entire time series (Fig. 8A), and for the case where $W$ remained constant with time and was set to $w_{s}$ the value of which was determined by the grid search method (Fig. 8B). Tank experiment data showed that sinking losses were not detectable before depletion of ambient nitrate. Therefore, modeled distributions shown in Fig. 8C \& D have sinking initiated after nitrate depletion. Chlorophyll and nitrate distributions are shown if sinking of cells occurred immediately after ambient nitrate depletion (Fig. 8C). In this case, $T_{\mathrm{s}}$ was set to the arbitrary low value of 0.0001 d. Finally, distributions are shown for the case where sinking of cells starts slowly after nitrate depletion, then accelerates (following a sigmoid function) to the maximum specific sinking rate (Fig. 8D). This was the best-fit equation as determined by F-ratio test (Moore \& McCabe 1993) (see Table 1). According to this chlorophyll-based model equation, the time scale for increased sinking after depletion of
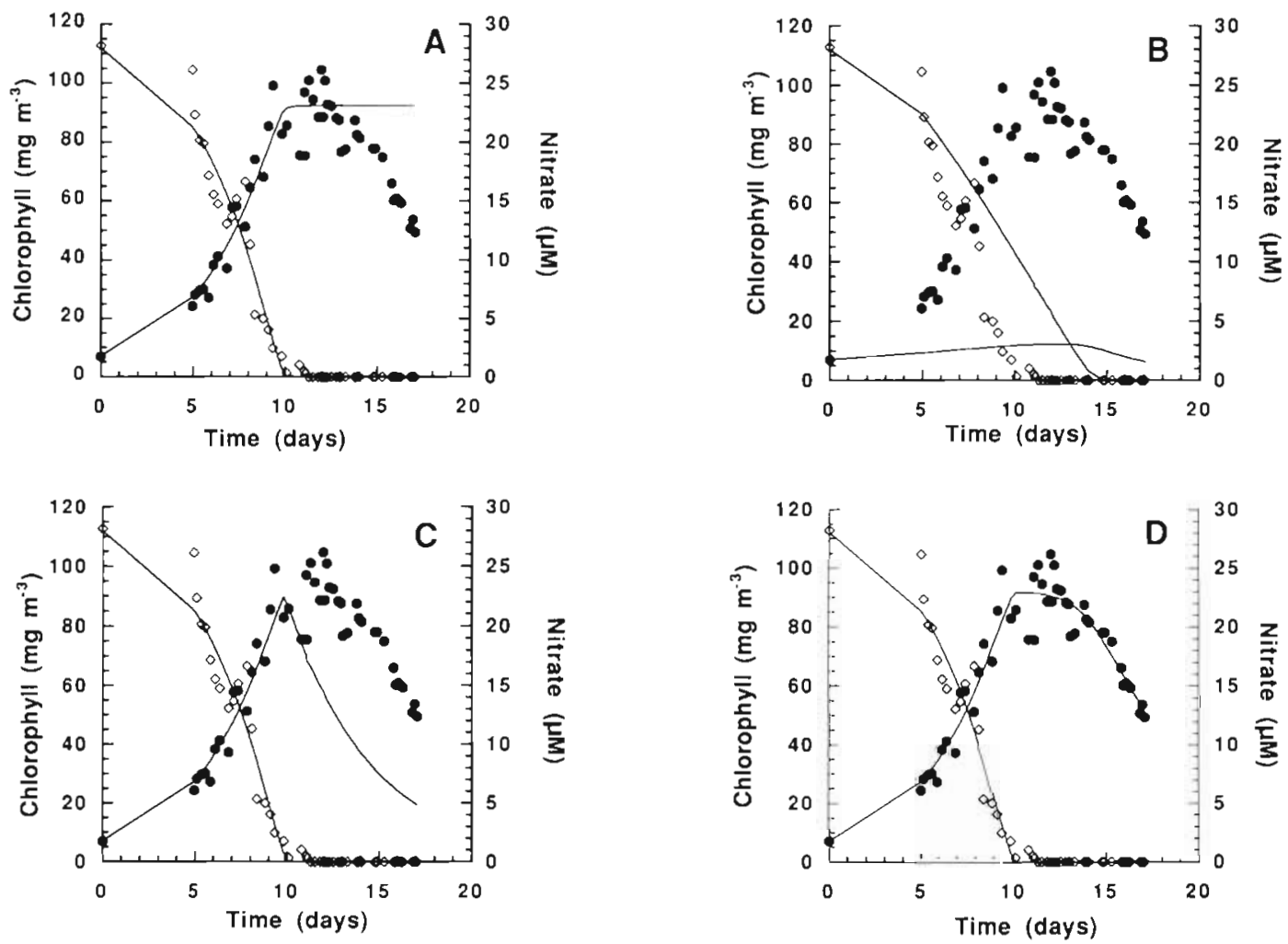

Fig. 8. Fits of model equations ( $\longrightarrow$ ) to observed chlorophyll ( $)$ and nitrate $(\diamond)$ data. (A) Fit of model equation with nitratedependent growth of cells but no sinking of biomass. (B) Fit of model equation with constant sinking rate. (C) Fit of model equation with no delay between depletion of ambient nitrate and initiation of sinking. (D) Fit of model equation with nitratedependent growth and nitrate-dependent sinking where cells reach $50 \%$ of their maximal sinking rate $115 \mathrm{~h}$ after depletion of ambient nitrate 
Table 1. F-ratio comparison of fits of 4 versions of Eq. (2) to observed surface chlorophyll distributions during growth of Thalassiosira weissflogii in the experimental tank. The 4 versions of Eq. (2) are: Model $\mathrm{A}=$ no sinking of biomass, Model $\mathrm{B}=$ constant sinking of biomass, Model $C=$ immediate nitrate-dependent sinking, Model $D=$ nitrate-dependent, sigmoid-shaped sinking function. We compare only the fit of Model D to the fits of the other 3 models. Values for sum of the squared deviations of modeled chlorophyll from observed values (SS dev model ${ }_{\text {obs }}$ ) were determined by spreadsheet calculations. Degrees of freedom (df) are the number of parameters in each model. The F-statistic is determined according to the equation:

$$
F \text {-statistic }=\frac{(\text { SS dev model } 1-\text { SS dev model } 2) \times(\text { df model } 2-\text { df model } 1)}{(\text { SS dev model } 2 / \text { No. of obs }- \text { df model } 2)}
$$

where model 1 and model 2 are designated such that model 1 has the higher sum of scuared deviations of the model from the observed data. F-ratio analysis shows that the fit of Model D is significantly better than the fits of the other 3 models at $p=0.001$, as the calculated $F$-statistics are all greater than the critical value of 56.18 (according to Table F, Moore \& McCabe 1993 )

\begin{tabular}{lccccc|}
\hline Comparison & SS dev model obs & df & No. of observations & Calculated F-statistic & Significant at $p=0.001$ ? \\
\hline Model D to & 2121 & 4 & 48 & 460.7 & Yes \\
Model A & 13224 & 2 & 48 & & Yes \\
Model D to & 2121 & 4 & 48 & 4878.19 & \\
Model B & 184247 & 3 & 48 & 810.15 & Yes \\
Model D to & 2121 & 4 & 48 & & \\
Model C & 41170 & 3 & & & \\
\hline
\end{tabular}

ambient nitrate was $25 \mathrm{~h}(1.04 \mathrm{~d})$. Thus, cells reach $10 \%$ of $w_{\mathrm{s}}$ approximately $62 \mathrm{~h}$ after nitrate depletion. The model equation also gave a maximum specific growth rate $\left(\mu_{\max }\right)$ of $0.3 \mathrm{~d}^{-1}$, a $K_{\mathrm{s}}$ value of $1.95 \mu \mathrm{M}$, and a maximum specific sinking (loss) rate of $0.22 \mathrm{~d}^{-1}$ This loss rate corresponds to a sinking rate of $0.04 \mathrm{~m} \mathrm{~d}^{-1}$ over an arbitrary surface stratum of $20 \mathrm{~cm}$.

An unknown component of the loss term (which we have considered due entirely to sinking) is due to the degradation of cellular chlorophyll upon nitrate depletion. Quantification of the degradation component is difficult. The use of chlorophyll data from batch culture experiments (which are not confounded by sinking losses) predicts a chlorophyll degradation rate of $0.14 \mathrm{~d}^{-1}$. If this rate is applied directly to the model immediately after nitrate depletion, it results in a gross overestimate of the actual loss of chlorophyll. In fact, it predicts that all the loss of chlorophyll from the surface of the tank could be from chlorophyll degradation. We know from rell count data, however, that cells were lost from the surface. This decline in cell numbers actually represents a minimum estimate of sinking losses, because cell division continues after the depletion of ambient nitrate (Fig. 5). The absence of a clearly defined relationship between cell numbers and nitrate disappearance precluded modeling cell numbers versus time, so the exact contribution of sinking to losses from the tank must lie somewhere between the minimum estimation from cell count data $0.1 \mathrm{~d}^{-1}$, according to a least-squares regression negative exponential curve fit) and the maximum specific loss rate of $0.22 \mathrm{~d}^{-1}$ determined by the model fit to chlorophyll data.

\section{Neutral buoyancy and sinking upon nitrate depletion}

Nutrient-replete Thalassiosira weissflogii exhibited nearly neutral buoyancy. There are at least 3 previous reports of neutral buoyancy in marine diatoms. In a similar experiment with a much larger tank, Strickland et al. (1969) observed neutral buoyancy during nitratereplete growth of the relatively large (cell length approx. $40 \mu \mathrm{m}$ ) diatom Ditylum brightwellii, but they did not run the experiment to complete exhaustion of nutrients. Eppley et al. (1967) noticed neutral buoyancy in $T$. weissflogii under specific culture conditions, and though they suspected that a fraction of these cells were neutrally buoyant in nature, they did no further investigation of this buoyancy or of the effects of nutrient depletion on buoyancy. Takahashi \& Bienfang (1983) found that natural populations of ultraplankton (size range $<3 \mu \mathrm{m}$ ) were neutrally buoyant, i.e. they had no measurable sinking rates. Both neutral and positive buoyancy have been reported for the large (>100 $\mu \mathrm{m}$ ) diatoms Rhizosolenia spp. and Ethmodiscus spp. (Villareal 1988, 1992).

Our observation of nearly neutral buoyancy in nitrate-replete Thalassiosira weissflogii was based upon the interpretation of chlorophyll profiles derived from in vivo fluorescence, which were then used as a proxy for biomass distribution. Though we recognize the inherent variability in fluorescence per chlorophyll and in chlorophyll per cell (as discussed above), cell counts done on surface samples agree with the pattern of biomass distribution inferred from chlorophyll profiles, and we believe that these profiles are representa- 
tive of changes in overall biomass distribution. However, one clarification is necessary: the conversion from fluorescence profiles to chlorophyll profiles was done using 3 to 5 direct chlorophyll measurements as calibration points, while values between these points were determined by linear interpolation. There was not always a surface sample taken for each profile, so apparent decreases in chlorophyll near the surface (see Fig. 6, for example) may be artifacts of extrapolating outside the range of measurements.

Thalassiosira weissflogii sank under nutrientdepleted conditions. It could be argued that sinking might have occurred at some critical concentration of biomass even if cells were not depleted of nutrients (Jackson 1990); however, the timing of the sinking response was consistent with changes in chemical composition (discussed in the next section) and with results previously reported in the literature. Much attention has been paid to the effects of nutrient depletion on cell sinking rate, though results in the literature are often contradictory. Steele \& Yentsch (1960) recognized early that nutrient status and cell buoyancy are closely related. Their experiments with Skeletonema costatum showed that sinking rates increased when nutrients were depleted from culture medium, but that sinking rates of nutrient depleted cells decreased considerably when cells were reenriched and placed in the dark. Later work that measured sinking rates of cells in relatively small columns (Bienfang 1981a) found that nitrate depletion caused either a decrease (Bienfang et al. 1982) or no significant change (Bienfang 1981b, Bienfang \& Harrison 1984. Bienfang et al. 1986) in cell sinking rates, though sinking rate increases were seen in response to depletion of other nutrients like phosphate and silicate (e.g. Bienfang \& Harrison 1984). More recent work on the dynamics of the sinking of spring blooms showed that termination and sinking of blooms occurred consistently at limiting nitrate concentrations (Waite et al. 1992a) and that Thalassiosira species were the most nutrient-sensitive, that is, their sinking rates increased most dramatically upon nitrate depletion (Waite et al. 1992b).

Some generalizations can be made between apparently contradictory evidence in the literature. Measurements which found no significant change in cell sinking rate with nitrate depletion were often done on natural populations which included a variety of phytoplankton types (e.g. Bienfang 1981b, Bienfang \& Harrison 1984), and all phytoplankton do not necessarily respond to nitrate depletion in the same way. There seems to be at least genus-specific differences in sensitivity to nitrate exhaustion (Waite et al. 1992a, b) as well as variation in sinking rates due to the pre-conditioning nutrient history of the population (Bienfang 1981b) and growth phase (Bienfang 1981c), so it is not surprising that there could be no obvious overall changes in sinking rates due to nutrient depletion. Different cells may react differently to nitrate depletion, but no change in the sinking rate of the population would be observed if sinking rates of mixed populations are measured using bulk biomass (not taxon specific) estimates such as total chlorophyll.

The early work of Steele \& Yentsch (1960) involved experiments with a monospecific culture (as was ours). while the later work of Waite et al. $(1992 a, b)$ dealt with blooms composed of only a few genera of diatoms (dominated by Thalassiosira aestivalis). Speciesspecific changes in cell sinking rates, therefore, should be more obvious for the case of monospecific populations than for more diverse assemblages of phytoplankton. Moreover, the termination of spring blooms due to nitrate exhaustion is similar to our 'bloom' and its termination in the tank.

The sinking of cells from surface waters of the tank occurred some time after the depletion of ambient nitrate. Chlorophyll data indicated that this sinking commenced approximately 24 to 48 h after ambient nitrate depletion. Cell count data, however, show that the time scale for increased sinking was closer to $60 \mathrm{~h}$. The time scale is likely underestimated by the chlorophyll data, as results from batch culture experiments and measured chlorophyll per cell during the tank experiment both show evidence of chlorophyll degradation. The model using chlorophyll as the biomass parameter thus overestimates actual sinking losses, as discussed earlier. Batch culture experiments showed little change in carbohydrate:protein ratios for the first $30 \mathrm{~h}$ after ambient nitrate depletion, then ratios increased rapidly to the end of the nitrate-depleted phase of the experiment. This indicates, perhaps, that cells were responding to depletion of internal nitrogen pools rather than to prevailing concentrations of nitrate, though no measurements of internal pools were made.

There is some support for delayed sinking in the literature. Bienfang (1981b) cites pre-conditioning nutrient history as a possible explanation for why he found no significant relationship between ambient nutrient concentrations and sinking rates of heterogeneous phytoplankton populations. In direct contrast to our work, however, Waite et al. (1992a) found that initiation of sinking of a spring bloom occurred before complete exhaustion of ambient nitrate, at threshold levels between 1 and $2 \mu \mathrm{M}$. It is not clear to us why these results differ, though increased aggregation of cells under low nutrient conditions (Kiørboe et al. 1990) may have played a role. We noticed no aggregation of Thalassiosira weissflogii during microscopic examination of surface samples taken from the tank. 


\section{Increased intracellular density as a result of unbalanced growth}

It is instructive to ask why nutrient-depleted cells sank from surface waters of the tank. Changes in cellular carbohydrate and protein during batch culture experiments could be responsible for changes in cell buoyancy observed during the tank experiment, so we performed calculations using literature values to determine how changes in carbohydrate and protein affect intracellular density of a model cell. Initial values of carbohydrate and protein per cell were taken from Myklestad (1974) for nutrient-replete cultures of Thalassiosira fluviatilis and were converted to carbohydrate per $\mu \mathrm{m}^{3}$ cell volume and protein per $\mu^{3}$ cell volume using cell volume data of Conover (1974) for the same organism. Resulting concentrations were $2.0 \times$ $10^{-7} \mu \mathrm{g} \mu \mathrm{m}^{-3}$ and $1.2 \times 10^{-7} \mu \mathrm{g} \mathrm{m}^{-3}$ for carbohydrate and protein, respectively.

Our model cell was composed only of carbohydrate, protein, and sea water. The total carbon pool of the cell, therefore, was determined by the total amount of carbon contained in carbohydrate and protein, assuming that carbohydrate (as laminarin) was $44.4 \%$ carbon and protein was $50 \%$ carbon by weight (West \& Todd 1963). Starting from initial values stated above, the weight of a $1 \mu^{3}$ volume was computed and expressed as density in units of $\mathrm{kg} \mathrm{m}^{-3}$. For this calculation, the densities of carbohydrate and protein were assumed to be $1600 \mathrm{~kg} \mathrm{~m}^{-3}$ and $1300 \mathrm{~kg} \mathrm{~m}^{-3}$, respec-

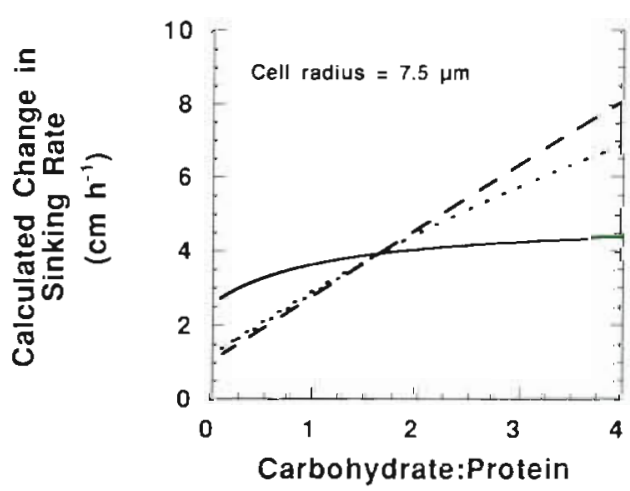

Fig. 9. Model output of changes in sinking rate expected with concurrent changes in carbohydrate:protein ratio for a model cell of radius $7.5 \mu \mathrm{m}$ (similar to the radius of Thalassiosira weissflogin). Solid line (-) shows expected sinking rate changes for a cell that keeps its total carbon content constant but shunts newly-acquired carbon into carbohydrate instead of protein (case 1). Dashed line (- -) shows expected sinking rate changes if a cell increases its carbohydrate but keeps both its protein and cell volume constant (case 2). Dotted line $(\cdot \cdots \cdot)$ shows expected sinking rate changes if a cell increases its carbohydrate, keeps its protein constant, but gradually increases its overall cell volume (case 3). See 'Discussion' for details tively (Oliver \& Walsby 1984). The remainder of the $1 \mu^{3}$ volume was assumed to be occupied by sea water. We then varied both the partitioning of total carbon (between carbohydrate and protein) and the total carbon pool to determine concurrent changes in intracellular density. To convert changes in intracellular density to changes in sinking rate of the model cell, we applied the equivalent changes in density to a cell of $7.5 \mu \mathrm{m}$ radius and computed sinking rate from Stokes' law for a sphere (Eq. 1), assuming a sea water density of $1029 \mathrm{~kg} \mathrm{~m}^{-3}$ and a dynamic viscosity of $1.072 \times 10^{-3}$ $\mathrm{kg} \mathrm{m}^{-1} \mathrm{~s}^{-1}$ at $20^{\circ} \mathrm{C}$ (Vogel 1981)

The relationship between sinking rate and carbohydrate:protein ratio was examined for 3 cases (Fig. 9). For case 1, we assumed that the total carbon content of the cell remained constant, but that the partitioning of carbon between carbohydrate and protein changed. Total volume of the cell was kept constant. Potential variations in cell volume due to changes in relative amounts of carbohydrate and protein were countered by changes in cell water content. For case 2, we assumed that cell protein remained constant, but that carbohydrate could increase or decrease. As with case 1 , changes in volume occupied by carbohydrate were balanced by changes in water content so that total volume of the cell remained constant. For case 3 , cell protein was held constant, carbohydrate was allowed to fluctuate, and the cell was allowed to get larger or smaller. Maximum change in cell radius within the range of the model was $\pm 8 \%$.

Model calculations (Fig. 9) show that the smallest ballast-related changes in sinking speed would be experienced by a cell that keeps its total carbon content constant, and merely shunts carbon acquired under nitrogen-depleted conditions into carbohydrate rather than protein. The greatest changes in cell sinking rate would be experienced by a cell that changes its cellular content of carbohydrate but keeps both its volume and its cellular content of protein constant. Intermediate between these values is the cell that changes its cellular carbohydrate and volume, but keeps its protein content constant. Over the course of nutrient depletion, that is, from carbohydrate:protein ratios of 0.1 to those of slightly less than 3.0 (the maximum range of carbohydrate:protein ratios determined during batch culture experiments, refer to Fig. $7 e$ ), these cells could experience changes in cell sinking rates of up to $4.5 \mathrm{~cm} \mathrm{~h}^{-1}$ or $1.1 \mathrm{~m} \mathrm{~d}^{-1}$ (using Fig. 9). It would take approximately $60 \mathrm{~h}$ for these changes to occur, which agrees well with the range of time scales for increased sinking determined during the tank experiment. During batch culture experiments, reversal of carbohydrate:protein ratios was rapid. Within $24 \mathrm{~h}$ after nitrate was added back to the medium, carbohydrate:protein values decreased to 1.0 from a value 
close to 3.0 (using Fig. 7E), which could translate to a sinking rate decrease $2.8 \mathrm{~cm} \mathrm{~h}^{-1}$ or $0.7 \mathrm{~m} \mathrm{~d}^{-1}$ (using Fig. 9). Overall, these calculations indicate that increases in carbohydrate ballast alone could have caused the changes in cell buoyancy observed during growth of Thalassiosira weissflogii in the experimental water column.

Though batch culture experiments and modeling exercises showed that increases in intracellular carbohydrate due to nitrate depletion could have resulted in the changes in buoyancy observed during the tank experiment, our calculations assume that the cell is composed only of carbohydrate, protein, and water. As this is untrue, calculated density changes and calculated sinking rates should be considered only as relative changes. They do not represent absolute values for cell sinking rates. True sinking rate of the cell will depend on many other factors, including silicification, ionic content, lipid content, and morphological characteristics (see review by Smayda 1970). The model of density change which allowed cell volume to increase is the more ecologically relevant, since cell volume tends to increase with growth of Thalassiosira weissflogii until cell division (Conover 1974).

Changes in intracellular density were calculated based only upon the measurement of carbohydrate as glucose equivalents which are detected by the phenolsulphuric acid method. Any incorporation of carbohydrate into storage products other than $\beta$-1,3-glucan (such as mannitol) was not measured and was not considered in our analysis, though this incorporation is usually less than $2 \%$ (see Myklestad 1978). Even without accounting for other storage products there was a substantial increase in calculated intracellular density due to $\beta$-1,3-glucans alone.

\section{Ecological consequences and biogeochemical implications of buoyancy changes and changes in chemical composition during unbalanced growth}

We have shown that Thalassiosira weissflogiu can be almost neutrally buoyant and that its sinking rate can change significantly (perhaps by as much as $1 \mathrm{~m} \mathrm{~d}^{-1}$ ) as the result of accumulation of carbohydrate during unbalanced growth. We have also shown that the chemical composition of $T$. weissflogii can revert rapidly upon exposure to nitrogen. These observations may have important ecological consequences. The model of Lande \& Wood (1987) showed that cells whose sinking rates slowed under nutrient-replete conditions spend a substantially longer total time in the surface mixed layer because of greater probability of re-entrainment back into the mixed layer. We did not show that the rates of cells sinking from the surface of the tank slowed once they reached the nutrient gradient. Data from batch cultures, however, showed clearly that the physiology of these cells is plastic enough to change intracellular density and thus permit fairly rapid buoyancy reversals. This would confer a distinct ecological advantage. According to the Lande \& Wood (1987) model, nutrient-dependent buoyancy changes allow cells to be shuttled between the top of the nutricline (where there is low light but high nutrient concentrations) and shallower depths (where there is high light but low or no nutrients). Access to both high light and high concentrations of nutrients may result in greater overall levels of primary productivity and growth than if buoyancy changes were not possible.

The vertical movements of phytoplankton represent an input of nitrogen to the euphotic zone and are a form of new production as defined by Dugdale \& Goering (1967). Because, in the dark, nitrate can be taken up without concurrent uptake of carbon (Terry 1982), cells will instead combine nutrients acquired at depth with carbon acquired in surface waters; that is, the processes of nutrient uptake and carbon uptake become uncoupled in space and time (Cullen 1985, Fraga et al. 1992). Thus, the input of nitrogen through vertical movements of cells is not coupled to the input of carbon in the Redfield ratio (Redfield 1958), as is the case for physically transported dissolved nutrients (see Eppley \& Peterson 1979). Since photosynthesis occurring in surface waters requires a carbon source, and since stoichiometric equivalents of carbon are not brought to the surface by cells in coupled transport with nitrogen, new production resulting from buoyancy-assisted uptake of nutrients could result in the net removal of carbon from oceanic surface waters which, in turn, could affect the air-sea exchange of carbon dioxide.

A clear example of the uncoupled movements of carbon and nitrogen due to vertical movements of phytoplankton was shown by Fraga et al. (1992) through their measurements of Broecker's parameters (Broecker 1974). These parameters, known as 'NO', ' $\mathrm{CO}$ ', and ' $\mathrm{PO}$ ', are intended to be conservative properties that characterize water masses. If biochemical reactions in the water mass are occurring in Redfield proportions, each of Broecker's parameters will be constant with depth. During a red tide of the dinoflagellate Gymnodinium catenatum, however, Fraga et al. (1992) found distinct vertical differences in their measurements of Broecker's parameters indicating that biochemical reactions in the water mass were not occurring in Redfield ratios. They attributed these deviations to vertical migrations by the dinoflagellates, whereby carbohydrate synthesis at the surface and nutrient uptake at depth resulted in a carbon deficit near the surface and a nitrogen deficit below. 
The ecological consequences of uncoupled carbon and nitrogen uptake have been outlined previously by Goldman et al. (1992). Similar to our observations during batch culture experiments with Thalassiosira weissflogii, Goldman et al. (1992) found uncoupling between photosynthesis and nutrient uptake in cultures of the diatom Stephanopyxis palmeriana. Carbon accumulation continued well into the stationary phase of the growth of this diatom, long after nutrients were depleted from the growth medium. Though $C: N$ uptake ratios during exponential (nutrient-replete) growth were in Redfield proportions (approximately 6:1), large deviations from Redfield stoichiometry occurred during the nutrient-depleted period of carbon accumulation (to $\mathrm{C}: \mathrm{N}$ ratios of 12:1). These observations are not restricted to laboratory experiments: removal of carbon from nutrient-depleted waters of the North Atlantic has been noted by Sambrotto et al. (1993) and Michaels et al. (1994). Goldman et al. (1992) point out the ecological consequences of unbalanced growth: the conventional definition of new production assumes that the flux of particulate organic carbon (POC) as new production can be calculated by multiplying new production as particulate organic nitrogen (PON) by the Redfield ratio of 6.6 (by atoms). It assumes a balance between the input of nutrients to the euphotic zone and the flux of organic matter to the deep ocean, even over short time scales. If, however, $\mathrm{C}: \mathrm{N}$ ratios are higher due to excess carbon accumulation during unbalanced growth, then the conventional definition of new production must be revised. By failing to consider the continuation of photosynthesis by some phytoplankton species after nutrient depletion, estimates of new production could be grossly underestimated (Goldman et al. 1992).

Goldman et al. (1992) also recognized the potential contributions of excess carbon accumulation to increased sinking speed of cells. In their study, nutrientdepleted cells formed highly condensed gelatinous masses, probably as the result of cellular excretion of complex heteropolysaccharides. Aggregation of these cells into large masses, and their subsequently high sinking speeds, would lead to direct export of cells from the euphotic zone with minimal losses to grazing. The loss of 'photosynthetically heavy' cells from the euphotic zone, however, is not necessarily an irreversible process. As we have shown by our batch culture experiments with Thalassiosira weissflogii, cells that have been accumulating carbon during unbalanced growth have the capacity to respond rapidly to increased nutrients, even after fairly long periods of nutrient deficiency (in our case up to 3 d). Rather than considering unbalanced growth and sinking as a one-way process, then, perhaps the process should be viewed as a cycle. That is, carbon accumulation provides adequate ballast to increase sinking speed, but the recovery from nutrient deficiency (perhaps to return to a state of increased buoyancy) allows cells to more easily return to the welllit waters of the euphotic zone. The observed recovery of cells from nutrient deficiency also lends support to the purported ability of cells to migrate vertically in nature (Villareal et al. 1993).

Thus, changes in cell buoyancy may be viewed as inherent consequences of cell physiology. The increase in cellular excess density provided by carbohydrate as the result of unbalanced growth followed by slowing of sinking rate due to uptake of nutrients and the use of stored carbohydrate is, in effect, a built-in buoyancy regulating mechanism. Rapid increases of cell sinking rate when cells are nutrient depleted and rapid returns to increased buoyancy when nutrient replete may represent an ecological adaptation to environments where light and nutrients are spatially separated.

Acknowledgements. Thanks to A. J. Bowen, M.-E. Carr, J. S. Craigie, M. R. Lewis and 3 perspicacious and genial reviewers for helpful comments on the manuscript. Thanks also to A. M. Ciotti for help with sampling and to Wade Blanchard for statistical advice. This study was supported by a grant from the Natural Sciences and Engineering Research Council (Canada) to J.J.C. and an Eliza Ritchie Doctoral Scholarship to T.L.R.

\section{LITERATURE CITED}

Anderson LWJ, Sweeney BM (1977) Diel changes in sedimentation characteristics of Ditylum brightwelli: changes in cellular lipid and effects of respiratory inhibitors and iontransport modifiers. Limnol Oceanogr 22:539-552

Anderson LWJ, Sweeney BM (1978) Role of inorganic ions in controlling sedimentation rate of a marine centric diatom Ditylum brightwellii. J Phycol 14:204-214

Beklemishev KB, Petrikova MN, Semina GI (1961) On the cause of buoyancy of plankton diatoms. Tr Inst Okeanol Akad Nauk SSSR 51:33-36

Bienfang PK (1981a) SETCOL - a technologically simple and reliable method for measuring phytoplankton sinking rates. Can J Fish Aquat Sci 38:1289-1294

Bienfang PK (1981b) Sinking rates of heterogeneous, temperate phytoplankton populations. J Plankton Res 3:235-253

Bienfang PK (1981c) Sinking rate dynamics of Cricosphaera carterae Braarud. II. Senescence response to various limiting substrates in non-steady state populations. J exp mar Biol Ecol 49:235-244

Bienfang PK, Conquest L, Antill E (1986) Compositional and buoyancy responses to nutrient deficiency in marine phytoplankton. Report of the Oceanic Institute, Makapuu Point, Waimanalo, HI

Bienfang PK, Harrison PJ (1984) Sinking-rate response of natural assemblages of temperate and subtropical phytoplankton to nutrient depletion. Mar Biol 83:293-300

Bienfang PK, Harrison PJ, Quarmby LM (1982) Sinking rate response to depletion of nitrate, phosphate, and silicate in four marine diatoms. Mar Biol 67:295-302

Bienfang PK, Szyper JP (1982) Effects of temperature and salinity on sinking rates of the centric diatom Ditylum bnghtwellii. Biol Oceanogr 1:211-223 
Bienfang PK, Szyper JP, Laws E (1983) Sinking rate and pigment responses to light-limitation of a marine diatom: implications to dynamics of chlorophyll maximum layers. Oceanol Acta 6:55-62

Broecker WS (1974) 'NO', a conservative water-mass tracer. Earth Planet Sci Lett 23:100-107

Conover SW (1974) Nitrate, ammonium, and urea as nitrogen. sources for marine diatoms in culture and in spring blooms. PhD thesis, Dalhousle University, Halifax

Cullen JJ (1985) Diel vertical migration by dinoflagellates: role of carbohydrate and behavioral flexibility. In: Rankin MA (ed) Migration: mechanisms and adaptive significance. Contr mar Sci 27 (Suppl ):135-152

Cullen J J, Horrigan S W (1981) Effects of nitrate on the diurnal vertical migration, carbon to nitrogen ratio, and the photosynthetic capacity of the dinoflagellate Gymnodinium splendens. Mar Biol 62:81-89

Cullen JJ, Lewis MR (1988) The kinetics of algal photoadaptation in the context of vertical mixing. J Plankton Res 10: 1039-1063

Dorsey TE, MacDonald P, Roels OA (1978) Measurement of phytoplankton protein content with the heated biuret folin assay. J Phycol 14:167-171

Dubois M, Gilles KA, Hamilton JK, Rebers PA, Smith F (1956) Colorimetric method for determination of sugars and related substances. Analyt Chem 28:350-356

Dugdale RC, Goering JJ (1967) Uptake of new and regenerated forms of nitrogen in primary productivity. Limnol Oceanogr 12:196-206

Eppley RW, Holmes RW, Strickland JDH (1967) Sinking rates of marine phytoplankton measured with a fluorometer. J exp mar Biol Ecol 1:191-208

Eppley RW, Peterson BJ (1979) Particulate organic matter flux and planktonic new production in the deep ocean. Nature $282: 677-680$

Fraga F, Pérez FF, Figueiras FG, Ríos AF (1992) Stoichiometric variations of $\mathrm{N}, \mathrm{P}, \mathrm{C}$ and $\mathrm{O}_{2}$ during a Gymnodinium catenatum red tide and their interpretation. Mar Ecol Prog Ser 87:123-134

Goldman JC, Hansell DA, Dennett MR (1992) Chemical characterization of three large oceanic diatoms: potential impact on water column chemistry. Mar Ecol Prog Ser 88: $257-270$

Granata TC (1987) Measurements of phytoplankton sinking and growth under varied light intensities and mixing regimes. PhD thesis, University of California, Berkeley

Gross F, Zeuthen E (1948) The buoyancy of plankton diatoms: a problem of cell physiology. Proc R Soc Lond (Ser B) 135: 382-389

Guillard RRL (1972) Culture of phytoplankton for feeding marine invertebrates. In: Smith WL, Chanley MH (eds) Culture of marine invertebrate animals. Plenum Press, New York, p 29-60

Hayward TL (1991) Primary production in the North Pacific Central Gyre: a controversy with important implications. Trends Ecol Evol 6:281-284

Heaney SI, Butterwick C (1985) Comparative mechanisms of algal movement in relation to phytoplankton production. In: Rankin MA (ed) Migration: mechanisms and adaptive significance. Contrib mar Sci 27 (Suppl):114-134

Heaney SI, Davey MC, Brooks AS (1989) Formation of subsurface maxima of a diatom within a stratified lake and in a laboratory water column. J Plankton Res 11:1169-1184

Heaney SI, Eppley RW (1981) Light, temperature, and nitrogen as interacting factors affecting diel vertical migrations of dinoflagellates in culture. J Plankton Res 3:331-344

Ibelings BW, Mur LR, Walsby AE (1991) Diurnal changes in buoyancy and vertical distribution in populations of Microcystis in two shallow lakes. J Plankton Res 13 419-436

Jackson GA (1990) A model of the formation of marine algal flocs by physical coagulation processes. Deep Sea Res 37 : $1197-1211$

Jahnke RA (1990) Ocean flux studies: a status report. Rev Geophys 28:381-398

Kahn N, Swift E (1978) Positive buoyancy through ionic control in the nonmotile marine dinoflagellate Pyrocystis noctiluca Murray ex Schuett. Limnol Oceanogr 23:649-658

Kiorboe T, Andersen K P, Dam H G (1990) Coagulation efficiency and aggregate formation in marine phytoplankton Mar Biol 107:235-245

Kirk JTO (1994) Light and photosynthesis in aquatic ecosys tems, 2nd edn. Cambridge University Press, Cambridge

Lande R, Wood AM (1987) Suspension times of particles in the upper ocean. Deep Sea Res 34:61-72

Michaels AF, Bates NR, Buesseler KO, Carlson CA, Knap AH (1994) Carbon-cycle imbalances in the Sargasso Sea. Nature 372:537-540

Michaels AF. Silver MW (1988) Primary production sinking fluxes and the microbial food web. Deep Sea Res 35: 473-490

Moore DS, McCabe GP (1993) Introduction to the practice of statistics, 2nd edn. WH Freeman and Company, New York

Myklestad S (1974) Production of carbohydrates by marine planktonic diatoms. I. Comparison of nine different species in culture. $J$ exp mar Biol Ecol 15:261-274

Myklestad S (1978) $\beta$-1, 3-glucans in diatoms and brown seaweeds. In: Hellebust JA, Craigie JS (eds) Handbook of phycological methods. II. Physiological and biochemical methods. Cambridge University Press. Cambridge, p $133-141$

Oliver RL (1994) Floating and sinking in gas-vacuolate cyanobacteria. J Phycol 30:161-173

Oliver RL, Walsby AE (1984) Direct evidence for the role of light-mediated gas vesicle collapse in the buoyancy regulation of Anabaena flos-aquae (cyanobacteria). Limnol Oceanogr 29:879-886

Redfield AC (1958) The biological control of chemical factors in the environment. Am Sci 46(3):1-221

Romans KM, Carpenter EJ, Bergman B (1994) Buoyancy regulation in the colonial diazotrophic cyanobacterium Trichodesmium tenue: ultrastructure and storage of carbohydrate, polyphosphate, and nitrogen. J Phycol 30:1-7

Roy S, Legendre L (1979) DCMU-enhanced fluorescence as an index of photosynthetic activity in phytoplankton. Mar Biol 55:93-101

Sambrotto RN, Savidge G, Robinson C, Boyd P, Takahashi T, Karl D, Langdon C, Chipman D, Marra J, Codispoti L (1993) Elevated consumption of carbon relative to nitrogen in the surface ocean. Nature 363:248-250

Smayda TJ (1970) The suspension and sinking of phytoplankton in the sea. Oceanogr mar biol A Rev 8:353-414

Smayda TJ, Boleyn BJ (1966a) Experimental observations on the flotation of marine diatoms. II. Skeletonema costatum and Rhizosolenia setigera. Limnol Oceanogr 11:18-34

Smayda TJ, Boleyn BJ (1966b) Experimental observations on the flotation of marine diatoms. III. Bacteriastrum hyalinum and Chaetoceros lauderi. Limnol Oceanogr 11 $35-43$

Smetacek VS (1985) Role of sinking in diatom life-history cycles: ecological, evolutionary and geological significance. Mar Biol 84:239-251

Steele JH, Yentsch CS (1960) The vertical distribution of chlorophyll. J mar biol Ass UK 39:217-226 
Strickland JDH, Holm-Hansen O, Eppley RW, Linn RJ (1969) The use of a deep tank in plankton ecology. I. Studies of the growth and composition of phytoplankton crops at low nutrient levels. Limnol Oceanogr 14:23-34

Strickland JDH, Parsons TR (1972) A practical handbook of seawater analysis, 2nd edn. Bull Fish Res Bd Can 167 $1-310$

Takahashi M, Bienfang PK (1983) Size structure of phytoplankton biomass and photosynthesis in subtropical Hawaiian waters. Mar Biol 76:203-211

Terry KL (1982) Nitrate uptake and assimilation in Thalassiosira weissflogii and Phaeodactylum tricornutum: interactions with photosynthesis and with the uptake of other ions. Mar Biol 69:21-30

van Rijn J, Shilo M (1985) Carbohydrate fluctuations, gas vacuolation and vertical migration of scum-forming cyanobacteria in fishponds. Limnol Oceanogr 30:1219-1228

Villareal TA (1988) Positive buoyancy in the oceanic diatom Rhizosolenia debyana H. Peragallo. Deep Sea Res 35 $1037-1045$

Villareal TA (1992) Buoyancy properties of the giant diatom Ethmodiscus. J Plankton Res 14:459-463

Villareal TA, Altabet MA, Culver-Rymsza K (1993) Nitrogen transport by vertically-migrating diatom mats in the North Pacific Ocean. Nature 363:709-712

Villareal TA, Carpenter EJ (1990) Diel buoyancy regulation in the marine diazotrophic cyanobacterium Trichodesmium thiebautii. Limnol Oceanogr 35:1832-1837

Vincent WF (1980) Mechanisms of rapid photosynthetic adap-

This article was submitted to the editor tation in natural phytoplankton communities. I. Changes in photochemical capacity as measured by DCMUinduced chlorophyll fluorescence. J Phycol 16:568-577

Vogel S (1981) Life in moving fluids: the physical biology of flow. Princeton University Press, Princeton, NJ

Waite A, Bienfang PK, Harrison PJ (1992a) Spring bloom sedimentation in a subarctic ecosystem. I. Nutrient sensitivity. Mar Biol 114:119-129

Waite A, Bienfang PK, Harrison PJ (1992b) Spring bloom sedimentation in a subarctic ecosystem. II. Succession and sedimentation. Mar Biol 114:131-138

Waite A, Thompson PA, Harrison PJ (1992C) Does energy control the sinking rates of marine diatoms? Limnol Oceanogr $37: 468-477$

Walsby AE (1978) The properties and buoyancy-providing role of gas vacuoles in Trichodesmium Ehrenberg. Br phycol J 13:103-116

Walsby AE, Reynolds CS (1980) Sinking and floating. In: Morris I (ed) The physiological ecology of phytoplankton. University of California Press, Los Angeles, p 371-412

Walsby AE, Reynolds CS, Oliver RL, Kromkamp J (1989) The role of gas vacuoles and carbohydrate content in the buoyancy and vertical distribution of Anabaena minutissima in Lake Rotongaio, New Zealand. Ergebn Limnol 32:1-25

Walsby AE, Xypolyta A (1977) The form resistance of chitin fibres attached to the cells of Thalassiosira fluviatilis Hustedt. Br phycol J 12:215-223

West ES, Todd WR (1963) Textbook of biochemistry, 3rd edn The MacMillan Company, New York

Manuscript first received: February 22, 1995

Revised version accepted: May 16, 1995 